\title{
Antimicrobial activity of needle essential oil of Pinus peuce Griseb. (Pinaceae) from Macedonian flora
}

\author{
Marija Karapandzova ${ }^{1 *}$, Gjose Stefkov$^{1}$, Elena Trajkovska-Dokic ${ }^{2}$, Ana Kaftandzieva², \\ Svetlana Kulevanova ${ }^{1}$
}

\author{
${ }^{1}$ Institute of Pharmacognosy, Faculty of Pharmacy, University "Ss. Cyril and Methodius”, Skopje, Macedonia \\ ${ }^{2}$ Institute of Microbiology, Faculty of Medicine, University "Ss. Cyril and Methodius”, Skopje, Macedonia
}

Received: January 2012; Accepted: March 2012

\begin{abstract}
Chemical composition and antimicrobial activity of needle essential oil, obtained by hydrodistillation from wild Pinus peuce Griseb. (Pinaceae), growing on three different locations in R. Macedonia were investigated in period 2008/2009. Carried out GC/FID/MS analysis, one hundred and three constituents were identified belonging to the six different classes of components: monoterpene hydrocarbons, oxygenated monoterpenes, sesquiterpene hydrocarbons, oxygenated sesquiterpenes, diterpenes and other non-terpene components, representing $88.61 / 94.04 \%$ of the entire oil. The most abundant constituents were $\alpha$-pinene $(12.89 / 27.34 \%), \beta$-pinene $(6.16 / 13.13 \%)$, limonene $+\beta$-phellandrene $(2.09 / 6.64 \%)$ and bornyl acetate $(2.92 / 11.67 \%)$ as well as trans-(E)-caryophyllene $(4.63 / 7.13 \%)$ and germacrene $\mathrm{D}(8.75 / 20.14 \%)$.

Antimicrobial screening of Pinus peuce needle essential oil was made by hole-plate diffusion and broth dilution method against 13 bacterial isolates of Gram positive and Gram negative bacteria and one strain of Candida albicans. The most sensitive bacteria against tested Pinus peuce essential oils were Streptococcus pneumonia encompassing Staphylococcus aureus, Staphylococcus epidermidis, Streptococcus agalactiae, Acinetobacter spp. and Streptococcus pyogenes. Minimal inhibitory concentrations (MICs) of the oils ranged from 7.5 $-62.5 \mu \mathrm{l} / \mathrm{ml}$.
\end{abstract}

Key words: Pinus peuce, Macedonian pine, essential oil composition, GC/FID/MS, antimicrobial activity.

\section{Introduction}

Representatives of genus Pinus in flora of R. Macedonia include five different species: Pinus nigra Arnold, Pinus sylvestris L., Pinus mugo Turra, Pinus heldreichii Christ. subsp. leucodermis (Antoine) Blecic and Pinus peuce Grisebach (Micevski, 1985). Most of the Pinus species are trees or shrubs with specific morphological characteristics of leaves (needles) rich in strong and terpenearomatic essential oil. Pine needle essential oils are mainly used in folk medicine for the treatment of respiratory in-

\footnotetext{
* Marija_Karapandzova@ff.ukim.edu.mk; marijakarapandzova@yahoo.com
}

fections accompanied by cough, bronchitis, bronchial asthma, emphysema, tracheitis, sinusitis, laryngitis, pharyngitis, tonsillitis and influenza (Dervendzi, 1992). Up to now, there has been an increased interest in studying chemical composition as well as biological activity of the essential oils isolated from different pine species. Generally, monoterpenes and sesquiterpenes like $\alpha$-pinene and $\beta$-pinene, camphene, $\Delta^{3}$-carene, $\beta$-myrcene, limonene, phellandrene, $\beta$-ocymene, $\beta$-caryophyllene, bornyl acetate, germacrene $\mathrm{D}$, cadinene and muurolene are mentioned as dominant components of pine needle essential oils (Roussis, 1994; Ucar, 2004; Tognolini, 2006; Naydenov, 2006, Idzojtic, 2005; Grassmann, 2003; Grassmann, 2005; Stevanovic, 2005; Ustun, 2006; Maciag, 2007; Judzentiene, 2006; Kupcinskiene, 2008; Semiz, 2007; Kainulainen, 
2002, Holzke, 2006; Dob, 2007; Menkovic, 1993; Nikolic, 2007; Dob, 2006; Pagula, 2006; Dormont, 1998; YongSuk, 2005; Oluwadayo, 2008; Sacchetti, 2005; Barnola, 2000). Some of these oils like essential oil isolated from Pinus caribaea Morelet, Pinus densiflora S. and Z., and Pinus radiate D. Don have showed different antimicrobial activity against different microorganisms (Oluwadayo, 2008; Yong-Suk, 2005; Sacchetti, 2005). The antimicrobial activity of pine essential oils is of multipurpose thus they are used in manufacture of medicinal products and cosmetics as antimicrobial additives, etc. Nowadays, there are few registered pharmaceuticals such as Pinimenthol ${ }^{\circledR}$, an ointment which contains pine needle essential oil and is particularly suitable for the treatment for upper respiratory tract infections both in adolescents and adults (Kamin, 2007).

Pinus peuce, known as "Molica" or "Macedonian pine" is an endemic species of Balkan Peninsula mostly spread in southern and western parts of R. Macedonia (Micevski, 1985), northern part of Greece and south-eastern parts of Bulgaria, as well as in parts of Albania, Serbia and Montenegro. Up to present, there are a lack of data that are related to the essential oil composition of Pinus peuce population from Macedonian flora and its antimicrobial activity, thus the aim to this study was to investigate the chemical composition of the needle essential oil of Pinus peuce from Macedonian flora and to assess its antimicrobial activity against certain types of microorganisms that affect respiratory, gastrointestinal and urogenital system and provoke pathological conditions on skin.

\section{Material and methods}

\section{Plant material}

Plant material was collected from four different localities in R. Macedonia: Baba Mtn. (Pelister), Nidze Mtn., Shara Mtn. and Karadzica Mtn. in July, 2008 and 2009, and was dried at room temperature and on draft for two weeks. Just before hydrodistillation, the needles were separated from the branches and were properly minced.

\section{Determination of water content}

Determination of water content was made by distillation according to Ph.Eur.7 regulations (2.2.13.) from $20 \mathrm{~g}$ dried plant material.

\section{Essential oil isolation}

Essential oil isolation was made by hydrodestillation in all-glass Clevenger apparatus (Ph.Eur 7, 2.8.12.). For that purpose, $20 \mathrm{~g}$ of minced needles were distilled for 4 hours. For purification purpose, anhydrous sodium sulfate was added to the isolated essential oil to remove residual water. For GC/FID/MS analysis, the essential oil was dissolved in xylene (Alkaloid, R. Macedonia) to obtain $1 \mu \mathrm{l} /$ $\mathrm{ml}$ oil solution.

\section{Gas chromatography}

Essential oil samples were analyzed on Agilent 7890A Gas Chromatography system equipped with FID detector and Agilent 5975C Mass Quadrupole detector as well as capillary flow technology which enables simultaneous analysis of the samples on both detectors. For that purpose, HP-5ms capillary column $(30 \mathrm{~m} \times 0.25 \mathrm{~mm}$, film thickness $0.25 \mu \mathrm{m})$ was used. Operating conditions were as follows: oven temperature at $60{ }^{\circ} \mathrm{C}(5 \mathrm{~min}), 1^{\circ} \mathrm{C} / \mathrm{min}$ to $80^{\circ} \mathrm{C}(2$ $\mathrm{min}$ ) and $5{ }^{\circ} \mathrm{C} / \mathrm{min}$ to $280^{\circ} \mathrm{C}(5 \mathrm{~min})$; helium as carrier gas at a flow rate of $1 \mathrm{ml} / \mathrm{min}$; injector temperature $260^{\circ} \mathrm{C}$ and that of the FID detector $270^{\circ} \mathrm{C} .1 \mu \mathrm{l}$ of each sample was injected at split ratio 1:1.

The mass spectrometry conditions were: ionization voltage $70 \mathrm{eV}$, ion source temperature $230^{\circ} \mathrm{C}$, transfer line temperature $280^{\circ} \mathrm{C}$ and mass range from $50-500 \mathrm{Da}$. The MS was operated in scan mode.

Identification of the components present in essential oils was made by comparing mass spectra of components in essential oils with those from Nist, Wiley and Adams mass spectra libraries, by AMDIS (Automated Mass Spectral Deconvolution and Identification System) and by comparing literature and estimated Kovat's (retention) indices that were determined using mixture of homologous series of normal alkanes from $\mathrm{C}_{9}$ to $\mathrm{C}_{25}$ in hexane, under the same above mentioned conditions.

The percentage ratio of essential oils components was computed by the normalization method of the GC/FID peak areas and average values were taken into further consideration $(n=3)$.

\section{Antimicrobial screening}

Antimicrobial activity of essential oils was studied against 14 different microorganisms, including 13 bacterial isolates representing both Gram-positive (Staphylococcus aureus ATCC 29213, Stahylococcus epidermidis, Streptococcus pneumoniae, Streptococcus agalactiae, Streptococcus pyogenes and Enterococcus) and Gram-negative bacteria (Acinetobacter spp, Escherichia coli ATCC 25927, Salmonella enteritidis, Klebsiella pneumoniae ATCC 700603, Pseudomonas aeruginosa ATCC 27853, Haemophylus influenzae and Proteus mirabilis) and one strain of Candida albicans ATCC 10231.

Hole-plate diffusion method was used for screening the antimicrobial activity of all essential oils (determination of growth inhibition zones of studied microorganisms that occur around certain essential oil). This investigation was followed by broth dilution method (determination of minimal inhibitory concentration MIC of the particular oil that had revealed good antimicrobial activity by hole-plate diffusion method). 


\section{Hole-plate diffusion method}

A nutrient agar (Mueller Hinton) was prepared by dissolving agar $(28 \mathrm{~g})$ in distilled water $(1000 \mathrm{ml})$. The mixture was heated to dissolve and autoclaved at $121{ }^{\circ} \mathrm{C}$ for 15 minutes. The nutrient agar was poured into sterile Petri dishes at uniform depth of $3 \mathrm{~mm}$ and allowed to solidify. Blood agar (Oxoid) was used for testing the antimicrobial activity against Streptococcus pyogenes, Streptococcus agalactiae, Streptococcus pneumoniae and Enterococcus, while Sabouraund agar (bioMerieux) was used for testing the antimicrobial activity against Candida albicans. Microorganisms were suspended in sterile broth with turbidity corresponding to 0.5 and $1 \mathrm{Mc}$ Farland (approximate by $10^{7}-10^{8} \mathrm{CFU} / \mathrm{ml}$ ) for all bacteria and for Candida albicans, respectively. The microbial suspensions were streaked over the surface of the agar media using a sterile cotton swabs to ensure uniform inoculation. After inoculation of microorganisms, holes of $6 \mathrm{~mm}$ in diameter were made at wellspaced intervals. They were filled with $85 \mu \mathrm{l}$ of $50 \%$ solutions of essential oils in dimethylsulfoxide (DMSO, Sigma-Aldrich, Germany) and one hole was filled only with DMSO as a control. The plates were incubated at $37{ }^{\circ} \mathrm{C}$, aerobically for 24 hours. The growth inhibition zones were measured after incubation of the isolates under their optimal growth conditions and were ranged between $6 \mathrm{~mm}$ and $30 \mathrm{~mm}$ in diameter. The antimicrobial activity was determined according to the diameters of the inhibition zones. If the diameter of the growth inhibition zones was in the range between 0 and $14 \mathrm{~mm}$, those species were accepted like resistant; if the diameter was between 14 and $19 \mathrm{~mm}$, the species were accepted like moderate susceptible and in the cases where the diameter was above $19 \mathrm{~mm}$, species were accepted like susceptible.

\section{Broth dilution method}

This method was used for some particular essential oil (50\% solution in DMSO) that had revealed good antimicrobial activity by hole-plate diffusion method. For that purposes, $25 \mu \mathrm{l}$ of those essential oils were diluted in equal quantities of $0.9 \%$ sodium chloride solution, to make them with the concentration of $25 \%$. This concentration was decreased five times, subsequently, by adding $25 \mu \mathrm{l}$ of each bacterial or fungal suspension, thus the final concentrations were: $12.5 \%, 6.25 \%, 3.125 \%, 1.562 \%$ and $0.75 \%$ or 125 $\mu \mathrm{l} / \mathrm{ml}, 62.5 \mu \mathrm{l} / \mathrm{ml}, 31.25 \mu \mathrm{l} / \mathrm{ml}, 15.26 \mu \mathrm{l} / \mathrm{ml}$ and $7.5 \mu \mathrm{l} / \mathrm{ml}$, respectively. $15 \mu$ of each bacterial or fungal suspensions with these particular concentrations were inoculated on solid media (Miller-Hinton agar, blood agar, Sabouraund agar), depending on the microorganism. The growth of any microorganism was evaluated after its incubation under the optimal growth conditions. The lowest concentration of essential oil which was able to inhibit the growth of the particular microorganism was considered as its minimal inhibitory concentration (MIC).

\section{Results and discussion}

Essential oil yield, calculated on anhydrous needles of Pinus peuce is given in Table 1. The obtained essential oils were transparent, agile, light yellowish liquids with specific and very strong turpentine odor.

Table 1. The yield* of Pinus peuce needle essential oils calculated on anhydrous plant material.

\begin{tabular}{lcc}
\hline Sample & $\begin{array}{c}\text { Water content } \\
(\mathrm{ml} / \mathrm{kg})\end{array}$ & $\begin{array}{c}\text { Yield* of essen- } \\
\text { tial oil }(\mathrm{ml} / \mathrm{kg}) \\
\pm \mathrm{SD}\end{array}$ \\
\hline Pelister Mtn. & 78.21 & $5.04 \pm 1.49 \%$ \\
Nidze Mtn. & 68.33 & $9.93 \pm 0.27 \%$ \\
Shara Mtn. & 93.75 & $9.24 \pm 2.86 \%$ \\
Karadzica Mtn. & 80.00 & $2.86 \pm 1.73 \%$ \\
\hline
\end{tabular}

$*(\mathrm{n}=3)$

Table 2 shows components that were identified in the Pinus peuce needle essential oils with their percentage amount and Kovat's retention indices. Given percentage values are averages of percentages of the components that are present in the essential oils obtained from plant material collected from various altitudes on four different localities: Pelister, Nidze, Shara and Karadzica Mtn.

Total of one hundred and three components were identified in the investigated samples of Pinus peuce needle essential oils. Analysis of the essential oils composition shows seasonal variations in the content of components that are present, probably due to the influence of weather conditions throughout the year. The most abundant components in all samples of isolated essential oils were monoterpenes: $\alpha$-pinene, $\beta$-pinene, limonene $+\beta$-phellandrene and bornyl acetate and sesquiterpenes: trans-(E)-caryophyllene and germacrene D. The content of each of these 6 components varies in relatively wide range but generally they are present in amounts from $2 \%$ to $28 \%$ and are likely to determine the physico-chemical characteristics as well as chemical profile of the oils. Large amount of monoterpenes camphene and $\alpha$-terpenil acetate and sesquiterpenes $\delta$-cadinene and $\alpha$-cadinol was observed in some essential oils samples (Table 2).

Needle essential oil isolated from plant material collected in 2008/2009 on Baba Mtn. (Pelister) contains $12.89 / 19.72 \% \alpha$-pinene, $6.16 / 7.95 \% \beta$-pinene, 3.08/3.97\% limonene $+\beta$-phellandrene, 9.29/10.56\% bornyl acetate, $4.88 / 7.13 \%$ trans (E)-caryophyllene and 8.75/19.90\% germacrene D. These dominant components represent $54.56 / 59.72 \%$ of the whole needle essential oil. Essential oil obtained from Pinus peuce collected in 2008 from Nidze Mtn. contains larger amount of $\alpha$-pinene $(27.34 \%)$, $\beta$-pinene $(10.73 \%)$ and limonene $+\beta$-phellandrene $(6.64 \%)$, but smaller amount of bornyl acetate (7.71\%). Among dom- 


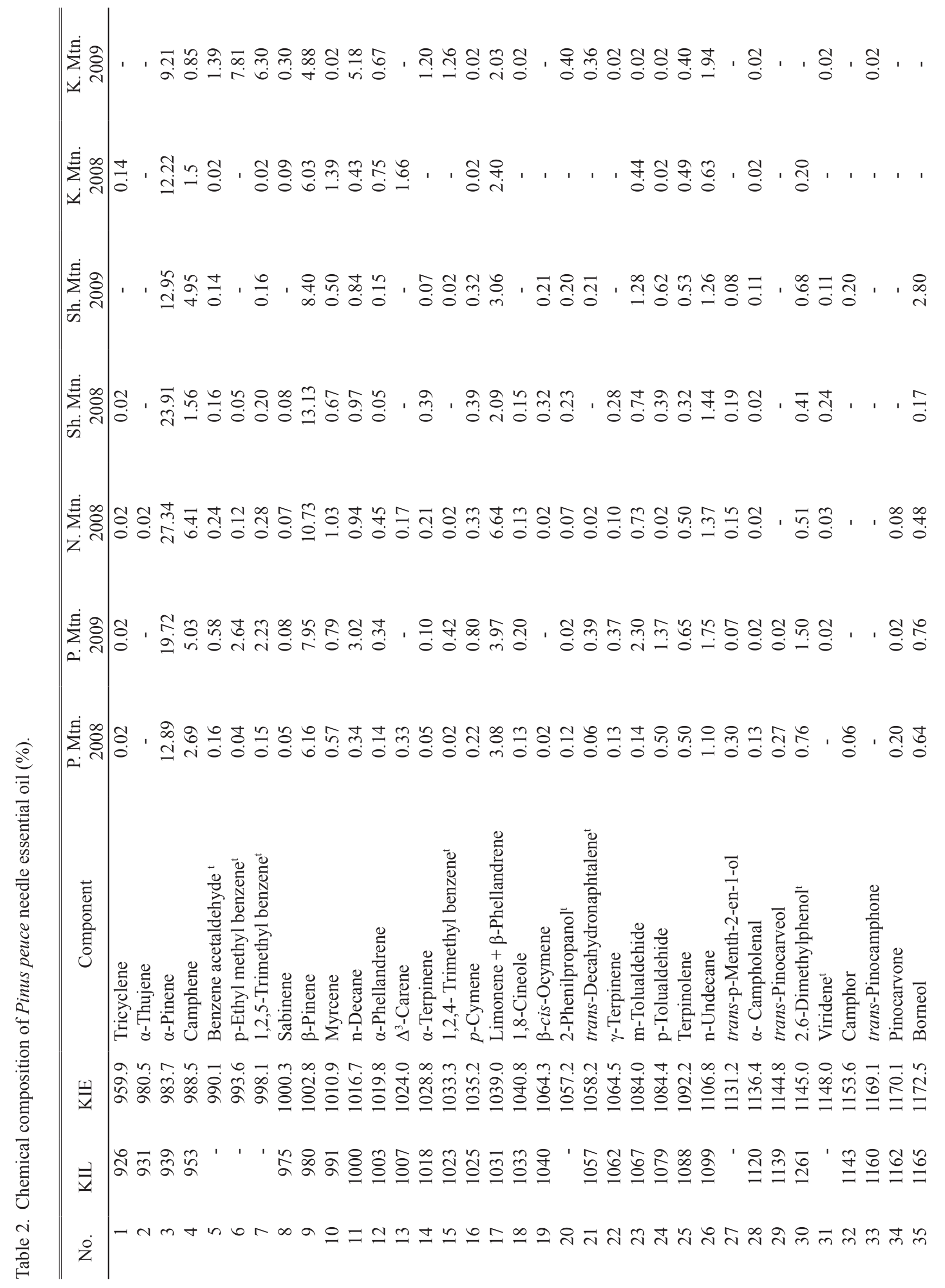




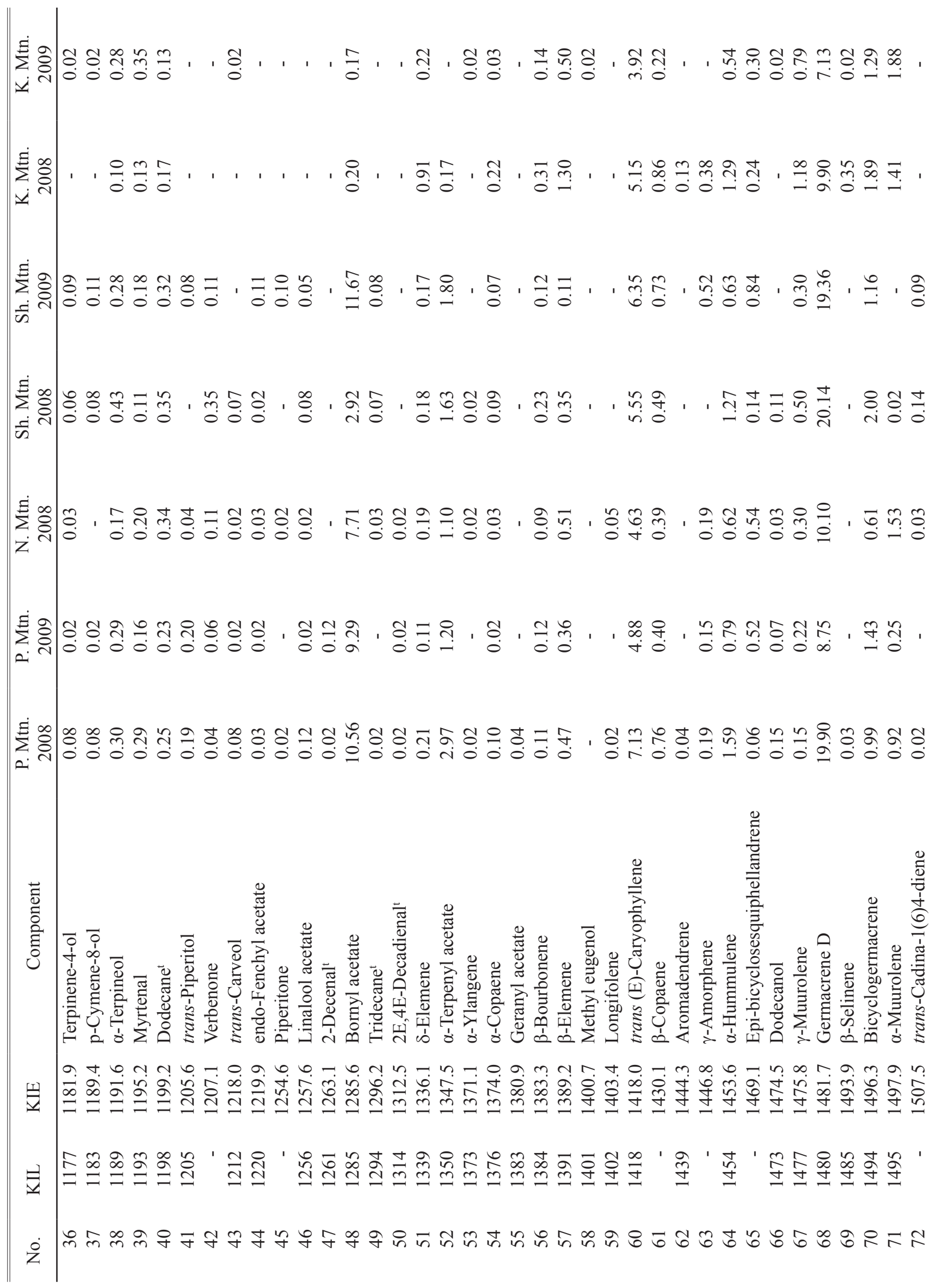

Макед. фарм. билт., 57 (1, 2) 25 - 36 (2011) 


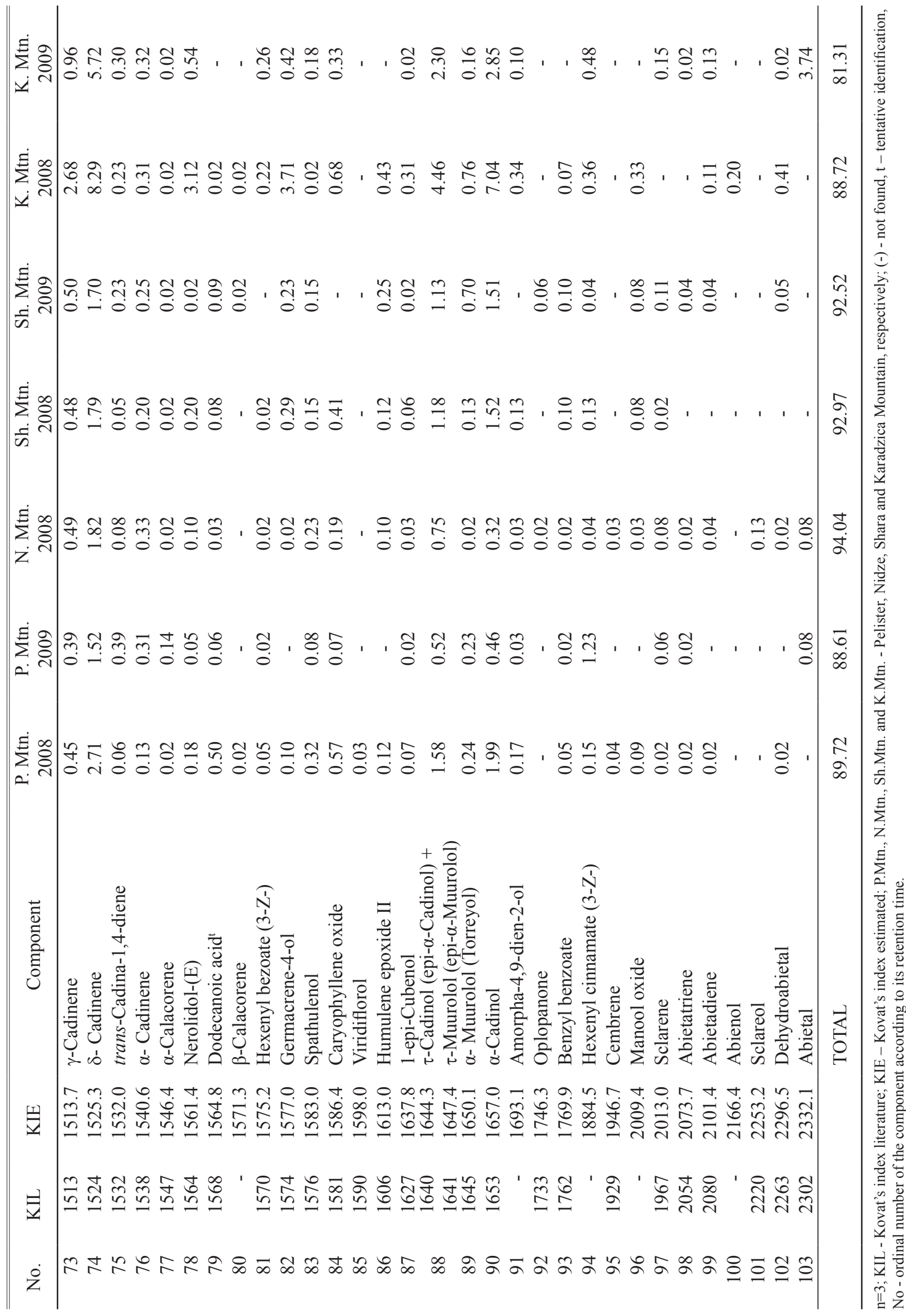


inant components in the essential oil obtained from plant material collected in 2008/2009 on Shara Mtn., $\alpha$-pinene $(12.95 / 23.91 \%), \beta$-pinene $(8.40 / 13.13 \%)$ and germacrene $\mathrm{D}(19.36 / 20.14 \%)$ were the most abundant while limonene $+\beta$-phellandrene $(2.09 / 3.06 \%)$ and bornyl acetate $(2.92 / 11.67 \%)$ were present in the smaller amount. These components represent $67.15 \%$ and $61.79 / 67.74 \%$ of whole needle essential oil isolated from Pinus peuce from Nidze and Shara Mtn., respectively. Essential oil composition of cultivated Pinus peuce from Karadzica Mtn. (samples collected in 2008/2009) is significantly different from the others essential oils mentioned above. This essential oil contains smaller amount of $\alpha$-pinene $(9.21 / 12.22 \%), \beta$-pinene $(4.88 / 6.03 \%)$, bornyl acetate $(0.17 / 0.20 \%)$ and germacrene $\mathrm{D}(7.13 / 9.90 \%)$, but it contains larger amount for two more components, $\delta$-cadinene $(5.72 / 8.29 \%)$ and $\alpha$-cadinol $(2.85 / 7.04 \%)$. Large amount of diterpene abietal (3.74\%) was measured in the essential oil isolated from plant material collected in 2009 .

Data analysis of the chemical composition of Pinus peuce needle essential oils revealed six different classes of components: monoterpene hydrocarbons, oxygenated monoterpenes, sesquiterpene hydrocarbons, oxygenated sesquiterpenes, diterpenes and other non-terpene components. Among different classes of components that are present in the essential oil isolated from plant material from Baba (Pelister), Nidze, Shara and Karadzica Mtn, the major constituents were terpene hydrocarbons $(62.44 \%$, $76.59 \%, 69.86 \%$ and $54.46 \%$, respectively) while oxygenated terpenes were present in smaller amount (Fig. 1.). The most abundant fraction among the total terpene amount were monoterpenes $(47.2 \%$ in essential oil samples from
Pelister, $62.16 \%$ in essential oil samples from Nidze Mtn. and $49.35 \%$ in samples from Shara Mtn.) (Fig.2.). Dominant sesquiterpene fraction $(45.23 \%)$ despite monoterpenes $(23.96 \%)$ is present only in the needle essential oils isolated from cultivated Pinus peuces from Karadzica Mtn. This is probably due to the environmental conditions that affect terpene biosynthesis of Pinus peuce in this region.

Up to now, there are only few data related to the chemical composition of Pinus peuce needle essential oils (Henning, 1994; Papadopoulou, 1996; Koukos, 2000; Petrakis, 2001; Nikolic, 2008; Karapandzova, 2010a; Karapandzova, 2010b; Karapandzova, 2011). Generally, there are some differences in chemical composition of essential oils isolated from Pinus peuce growing in Greece, Serbia and Montenegro in terms of presence of the dominant components in the oil. Compared with essential oils isolated from Pinus peuce from Macedonia, the needle essential oil isolated from Pinus peuce from Greece contain larger amount of $\beta$-pinene $(22.00 \%)$ and citronellol $(13.42 \%)$, smaller amount of trans (E)-caryophyllene (3.05\%), but it doesn't contain germacrene D (Koukos, 2000). On the other hand, the needle essential oil isolated from Pinus peuce from Montenegro and Serbia contain larger amount of $\alpha$-pinene (36.5\%) and camphene (8.5\%) (Nikolic, 2008).

The most sensitive bacteria against tested needle essential oils were Streptococcus pneumoniae. Streptococcus agalactiae showed similar sensitivity as previous bacteria and was susceptible to the effects of needle essential oils isolated from Pinus peuce from Shara and Nidze Mtn. as well as moderate susceptible to the effects of the needle essential oil from Pelister. Streptococcus pyogenes was susceptible to the effects of essential oils isolated from

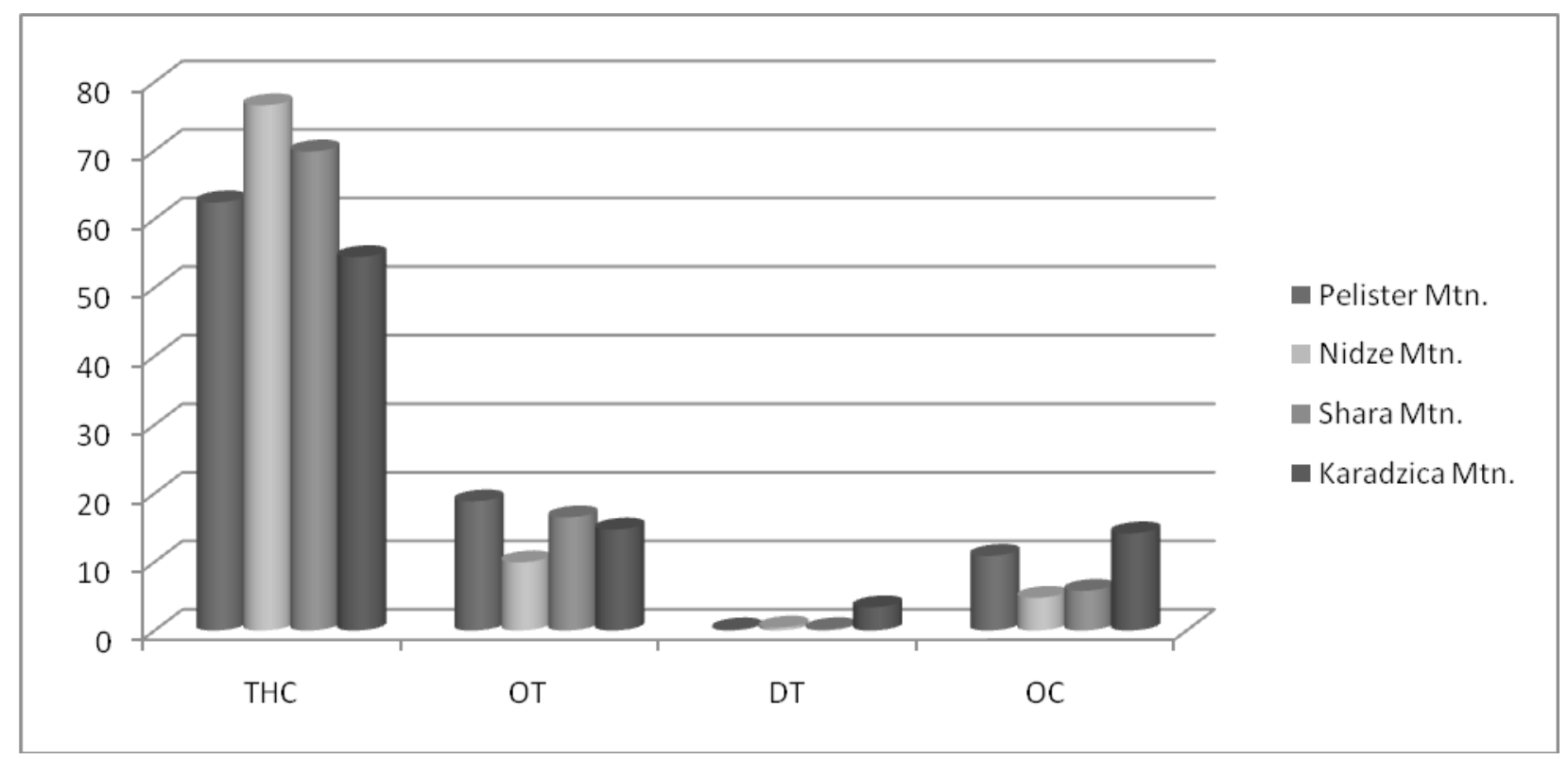

Fig. 1. Abundance of terpene hydrocarbons (THC) and oxigenated terpenes (OT) regarding diterpenes (DT) and other components (OC) in Pinus peuce needle essential oils. 


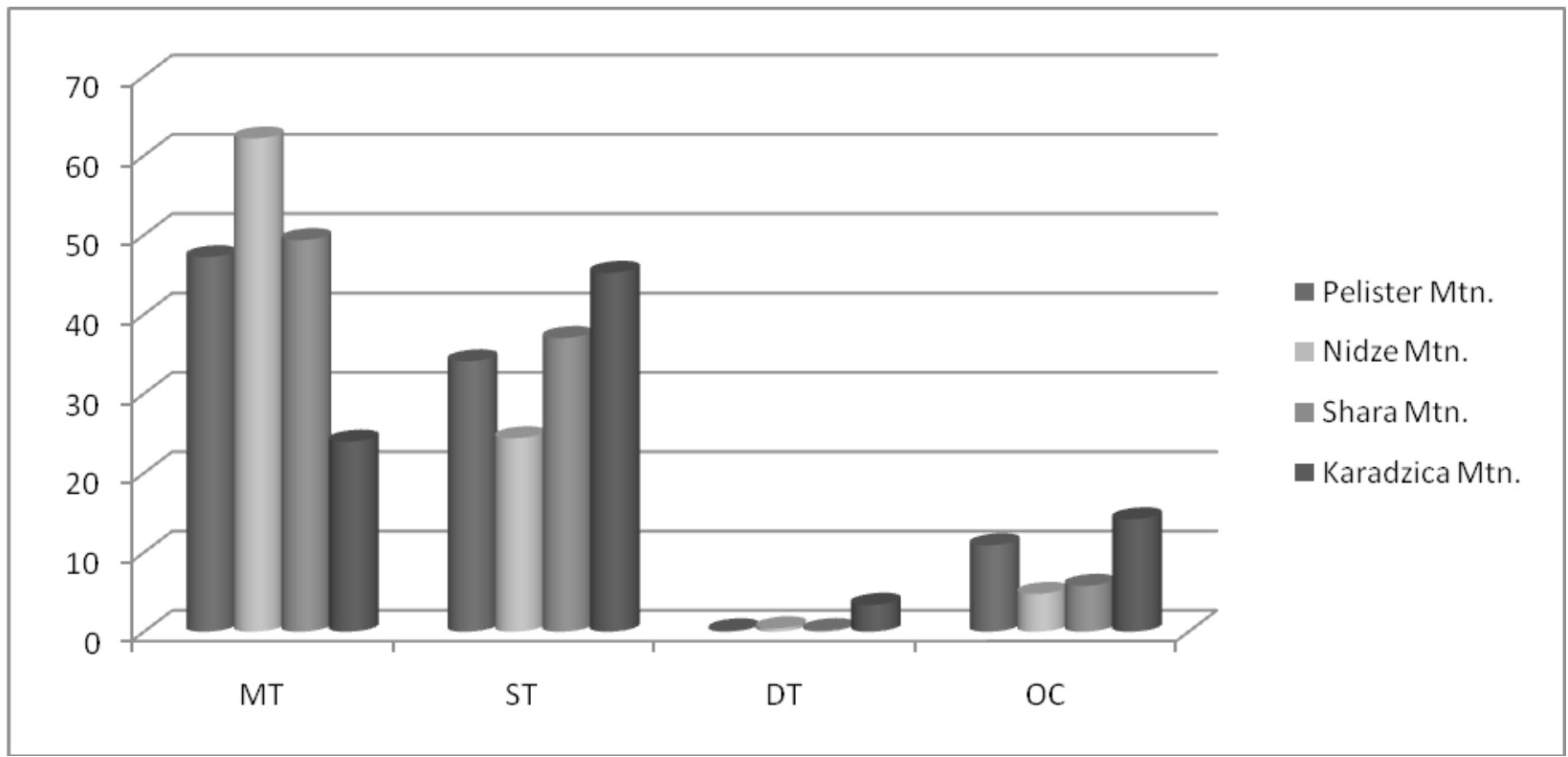

Fig. 2. Abundance of monoterpenes (MT), sesquiterpenes (ST), diterpenes (DT) and other components (OC) in Pinus peuce needle essential oils.

Pinus peuce from Shara Mtn. and moderate susceptible to the essential oils from Pelister and Nidze Mtn. Bacteria such as Staphylococcus aureus, Staphylococcus epidermidis and Acinetobacter spp. showed sensitivity to the effects of essential oils isolated from plant material collected from Pelister and Nidze Mtn. Other investigated bacteria and Candida albicans were resistant to the antimicrobial effects of the Pinus pence needle essential oils.

Summarizing the obtained results it is evident that the essential oil isolated from Pinus peuce from Pelister showed antimicrobial effect toward Streptococcus pneumoniae, Staphylococcus aureus, Staphylococcus epidermidis and Acinetobacter spp. Essential oil isolated from plant material from Shara Mtn. showed antimicrobial activity against Streptococcus pneumoniae, Streptococcus agalactiae and Streptococcus pyogenes, while the needle essential oil from Pinus peuce from Nidze Mtn. showed effects against Streptococcus pneumoniae, Staphylococcus aureus, Staphylococcus epidermidis, Streptococcus agalactiae and Acinetobacter spp. (Fig. 3.). This essential oil showed the best antimicrobial activity among all tested $P i$ nus peuce needle essential oils.

Minimal inhibitory concentration (MIC) values of $P i$ nus peuce needle essential oils for tested microorganisms determined by broth dilution method are given in Table 3. The lowest MIC (less than $7.5 \mu \mathrm{l} / \mathrm{ml}$ ) is determined in essential oil isolated from Pinus peuce from Shara Mtn. against Streptococcus pyogenes, while the highest MIC value $(62.5 \mu \mathrm{l} / \mathrm{ml})$ is determined in essential oil obtained from plant material collected on Baba Mtn. (Pelister) toward Staphylococcus aureus.
Table 3. Minimal inhibitory concentrations (MIC) of Pinus peuce needle essential oils determined by broth dilution method $(\mu \mathrm{l} / \mathrm{ml})$.

\begin{tabular}{|c|c|c|c|}
\hline \multirow[b]{2}{*}{ Microorganism } & \multicolumn{3}{|c|}{$\operatorname{MIC}(\mu 1 / \mathrm{ml})$} \\
\hline & $\begin{array}{l}\text { Pelister } \\
\text { Mtn. }\end{array}$ & $\begin{array}{l}\text { Shara } \\
\text { Mtn. }\end{array}$ & $\begin{array}{l}\text { Nidze } \\
\text { Mtn. }\end{array}$ \\
\hline $\begin{array}{l}\text { Streptococcus } \\
\text { pneumoniae }\end{array}$ & 31.25 & 15.62 & 15.62 \\
\hline $\begin{array}{l}\text { Staphylococcus } \\
\text { aureus }\end{array}$ & 62.5 & n.a. & 31.25 \\
\hline $\begin{array}{l}\text { Staphylococcus } \\
\text { epidermidis }\end{array}$ & 31.25 & n.a. & 15.62 \\
\hline $\begin{array}{l}\text { Streptococcus } \\
\text { agalactiae }\end{array}$ & n.a. & 31.25 & 15.62 \\
\hline $\begin{array}{l}\text { Streptococcus } \\
\text { pyogenes }\end{array}$ & n.a. & $<7.5$ & n.a. \\
\hline Enterococcus & n.a. & n.a. & n.a. \\
\hline $\begin{array}{l}\text { Haemophilus } \\
\text { influenzae }\end{array}$ & n.a. & n.a. & n.a. \\
\hline $\begin{array}{l}\text { Acinetobacter } \\
\text { spp. }\end{array}$ & 31.25 & n.a. & 31.25 \\
\hline $\begin{array}{l}\text { Escherichia } \\
\text { coli }\end{array}$ & n.a. & n.a. & n.a. \\
\hline $\begin{array}{l}\text { Salmonella } \\
\text { enteritidis }\end{array}$ & n.a. & n.a. & n.a. \\
\hline $\begin{array}{l}\text { Candida } \\
\text { albicans }\end{array}$ & n.a. & n.a. & n.a. \\
\hline
\end{tabular}

n.a. - no activity found 

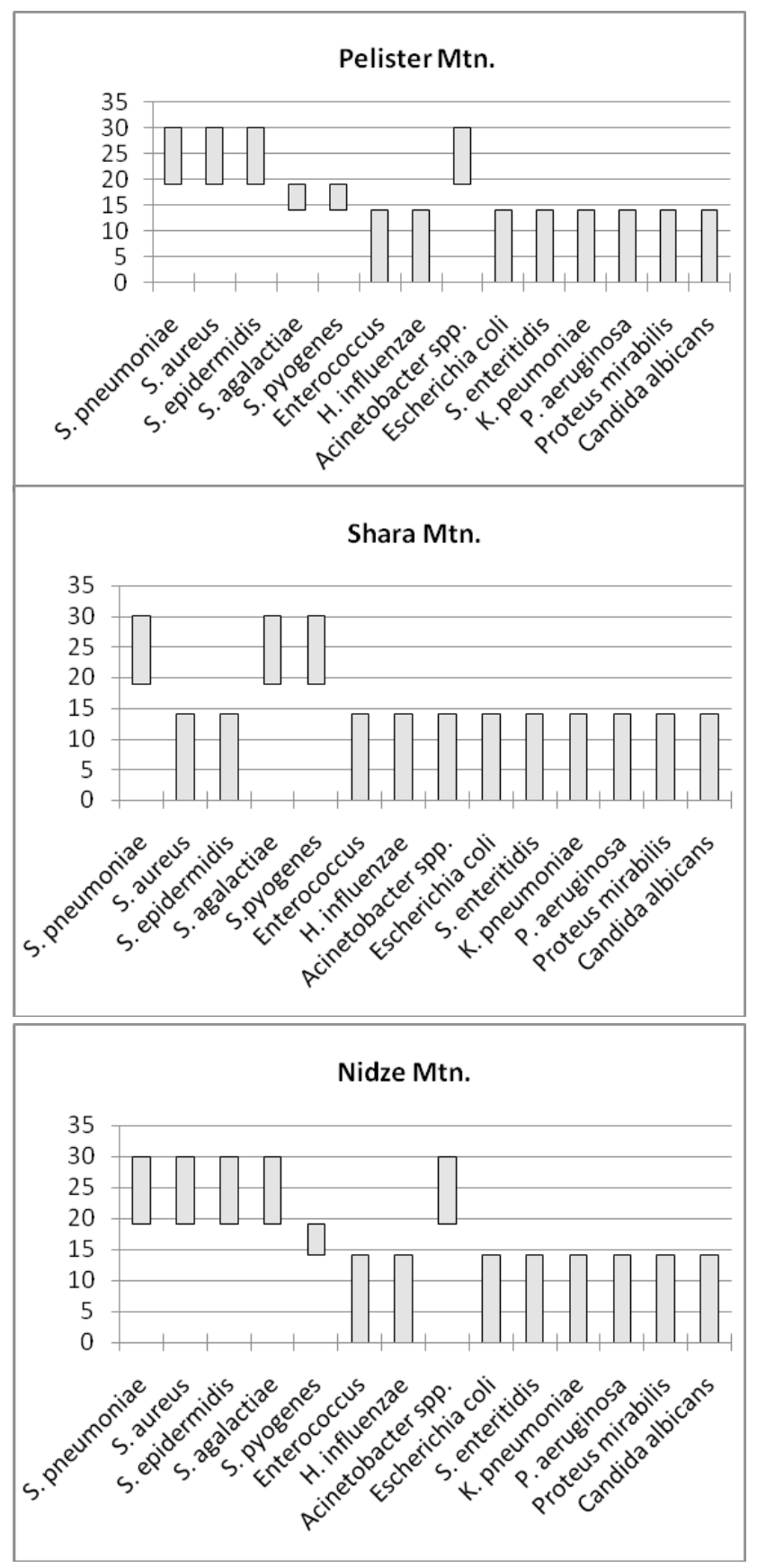

Fig. 3. Antimicrobial activity (growth inhibition zones in $\mathrm{mm}$ ) of Pinus peuce needle essential oils determined by hole-plate diffusion method: $0-14 \mathrm{~mm}$ resistant, 14-19 mm moderate susceptible and 19$30 \mathrm{~mm}$ susceptible microorganisms.

Although the biological activity of essential oils is well known, the mode of their action is not completely understood. Generally, the activity of essential oils is the result of the combined effect both of their active and inactive components. Inactive components may affect resorption, speed of reaction and bioavailability of active components (Colgate, 1993; Svoboda, 1995), while the active components can have a synergistic effect. Essential oils are familiar with antibacterial, antifungal and antiviral activity. Many studies have explained antibacterial activity of essential oils against Gram-positive and Gram-negative bacteria (Reichling, 1999a; Weseler, 2005; Reichling, 1999b; Youesf, 1980; Dorman, 2000; Takarada, 2004) and have confirmed their antifungal activity (Hammer, 1998). There are differences in the biological activity of essential oils, especially when it comes to different strains of Gram-positive and Gram-negative bacteria. The different susceptibility of bacteria to the action of essential oils are not only due to a different chemical composition of the oils, but the differences in the composition and structure of the cell wall, lipid and protein composition of cytoplasmic membrane and specific physiological processes in different bacterial species. The way and mechanism of antibacterial activity of essential oils are not sufficiently explained yet. Nowadays, it is accepted that some essential oils and their components mainly act on bacterial cytoplasmic membrane (Ulrich, 2008). According to the literature data, there are only three references that are related to the antimicrobial screening of pine needle essential oils. Oluwadayo et al. (2008) reported that the major constituents of essential oils isolated from the needles of Pinus caribaea Morelet are $\beta$-phellandrene (67.9\%), $\beta$-caryophyllene (10.2\%) and $\alpha$-pinene (5.4\%). This essential oil exhibited moderate activity against Pseudomonas aeruginosa at minimum inhibitory concentration of $1000 \mu \mathrm{l} / \mathrm{ml}$ and no activity against other investigated microorganisms as Candida albicans, Bacillus subtilis, Staphylococcus typhi, Bacillus aureus and Proteus mirabilis. According to Sacchetti et al. (2005), the most abundant components of Pinus radiata D. Don are $\beta$-pinene (35.21\%), $\alpha$-pinene (21.9\%), $\beta$-phellandrene $(12.6 \%)$, iso-silvestrene $(8.42 \%)$, $\alpha$-terpineol $(3.01 \%)$, terpinolene $(2.21 \%)$, estragole $(2.07 \%)$ and citronellol $(1.87 \%)$. This essential oil showed a moderate inhibiting activity against tested yeasts as Candida albicans, Rhodotorula glutinis, Schizosaccharomyces pombe, Saccharomycea cerevisiae and Yarrowia lypolitica at minimum inhibitory concentrations of $0.14,0.09,0.02,0.06$ and 0.29 $\mathrm{mg} / \mathrm{ml}$, respectively. The antimicrobial effects of volatile components extracted from needles of Pinus densiflora S. and Z. was examined by Youg-Suk et al. (2005). $\alpha$-Ocimene (29.3\%), sabinene (10.9\%), $\beta$-myrcene $(9.6 \%)$, $\beta$-caryophyllene (8.0\%), $\beta$-cadinene (7.3\%), $\alpha$-terpinolene (4.9\%), 2-hexanal (4.5\%) and $\beta$-pinene (4.3\%) were considered as dominant components. Antimicrobial activity was screening against six different microorganisms: $B a-$ cillus cereus, Salmonella typhimurium, Vibrio parahaemolyticus, Listeria monocytogenes, Staphylococcus aureus and Escherichia coli. Among tested microorganisms, the growth of Bacillus cereus, Salmonella typhimurium and Staphylococcus aureus was completely inhibited.

Compared to our results, composition of Pinus peuce needle essential oil differs a lot from above tested pine oils. Antimicrobial screening was performed on different bacterial and fungi strains. All mentioned results indicate that the 
antimicrobial activity of pine needle essential oils depend on the type of microorganism as well as chemical composition of the oil. For example, antimicrobial activity of $P i$ nus radiata essential oil against Candida albicans is probably due to the higher amount of $\alpha$-pinene $(21.9 \%)$ and $\beta$-pinene (35.21\%) in comparison with Pinus peuce needle essential oil which contains lower amounts of these two components and hasn't showed antimicrobial effect against tested fungi. On the other hand, the mechanism of antimicrobial activity of needle essential oil from different pine species has not been clarified yet thus the action of essential oils on bacterial cytoplasmic membrane may be considered as a superior mechanism of antimicrobial activity of Pinus peuce needle essential oil.

\section{Conclusion}

The yield of needle essential oils obtained by hydrodistillation of Pinus peuce from Pelister, Nidze, Shara and Karadzica Mtn. ranged from 5.04, 9.24, 9.93 and $2.86 \mathrm{ml} /$ $\mathrm{kg}$, respectively. The obtained essential oils were transparent, agile, light yellowish liquids with specific and very strong turpentine odor.

Using GC/FID/MS, one hundred and three components were identified in the Pinus peuce needle essential oils. The most abundant components in all samples of isolated oils were monoterpenes: $\alpha$-pinene, $\beta$-pinene, limonene $+\beta$-phellandrene and bornyl acetate and sesquiterpenes: trans-(E)-caryophyllene and germacrene $\mathrm{D}$.

The most sensitive bacteria against tested Pinus peuce needle essential oils were Streptococcus pneumoniae, while Streptococcus agalactiae, Streptococcus pyogenes, Staphylococcus aureus, Staphylococcus epidermidis and Acinetobacter spp. showed different sensitivity to the antimicrobial effects of the essential oils deepening on the area of collection of plant material. Essential oil obtained from plant material collected from Nidze Mtn. showed the highest antimicrobial activity against tested microorganism.

As the most promising activity of Pinus peuce needle essential oil was found against Streptococcus pneumoniae, this oil could be recommend for inhalation for infections of upper respiratory tract or for treatment of different skin condition provoked by Staphylococcus aureus. Further examination of safety of Pinus peuce needle essential oil should be done before their final recommendation.

\section{References}

Barnola, L.F., Cedeno, A., 2000. Inter-population differences in the essential oils of Pinus caribaea needles. Biochemical Systematics and Ecology 28, 923-931.

Colgate, S.M., Molyneux, R.J., 1993. Bioactive Natural Products - Detection, Isolation and Structural Determination. CRC Press: Boca Raton. 9-34.

Dervendzi, V., 1992. Sovremeno lekuvanje so lekoviti bilki, Tabernakul, Skopje. 81-83.
Dob, T., Berramdane, T., Chelghoum, C., 2006. Analysis of essential oil from the needles of Pinus pinaster growing in Algeria. Chemistry of Natural Compounds 41, 545-548.

Dob, T., Berramdane, T., Chelgoum, C., 2007. Essential oil composition of Pinus halepensis Mill. from three different regions of Algeria. Journal of Essential Oil Research 19 (1).

Dorman, H.J., Deans, S.G., 2000. Antimicrobial agents from plants: antibacterial acivity of plant volatile oils. J. Appl. Microbiol. 88, 308-316.

Dormont, L., Roques, A., Malosse, C., 1998. Cone and foliage volatiles emitted by Pinus cembra and some related conifer species. Phytochemistry 49, 1269-1277.

Grassmann, J., Hippeli, S., Spitzenberger, R., Elstner, E.F., 2005. The monoterpene terpinolene from the oil of Pinus mugo L. in concert with $\alpha$-tocopherol and $\beta$-carotene effectively prevents oxidation of LDL. Phytomedicine 12, 416-423.

Grassmann, J., Hippeli, S., Vollmann, R., Elstner, E.F., 2003. Antioxidative properties of the essential oil from Pinus mugo. J. Agric. Food Chem. 51, 7576-7582.

Hammer, K., Carson, C.F., Riley, T.V., 1998. In-vitro activity of essential oils, in particular Melaleuca alternifolia (tea tree) oil and tea tree oil products against Candidia sp.. Antimicrob Agents Chemother. 42, 591-595.

Henning, P., Steinborn, A., Engewald, W., 1994. Investigation of the composition of Pinus peuce needle oil by GC-MS and GC-GC-MS. Chromatographia 38, 689-693.

Holzke, C., Hoffmann, T., Jaeger, L., Koppmann, R., Zimmer, W., 2006. Diurnal and seasonal variation of monoterpene and sesquiterpene emissions from Scots pine (Pinus sylvestris L.). Atmospheric Environment 40, 3174-3185.

Idzojtic, M., Kajba, D., Franjic, J., 2005. Differentiation of $F_{1}$ hybrids $P$. nigra J.F. Arnold x P. sylvestris L., P. nigra J.F. Arnold x P. densiflora Siebold et Zucc., P. nigra J.F. Arnold x $P$. thunbergiana Franco and their parental species by needle volatile composition. Biochemical Systematics and Ecology 33, 427-439.

Judzentiene, A., Slizyte, J., Stikliene, A., Kupcinskiene, E., 2006. Characteristics of essential oil composition in the needles of young Scots pine (Pinus sylvestris L.) stands growing along an aerial ammonia gradient. Chemija 17 (4), 67-73.

Kainulainen, P., Holopainen, J.K., 2002. Concentrations of secondary compounds in Scots pine needles at different stages of decomposition. Soil Biology and Biochemistry 34, $37-42$.

Kamin, W., Kieser, M., 2007. Pinimethol ointment in patients suffering from upper respiratory tract infections - A postmarketing observational study. Phytomedicine 14, 787-791.

Karapandzova, M., Stefkov, G., Trajkovska-Dokik, E., Kadifkova-Panovska, T., Kaftandzieva, A., Petrovski, O., Kulevanova, S.,2010a. Chemical composition of essential oil of Pinus peuce (Pinaceae) from Macedonian flora and its antimicrobial activity. Planta Medica 76, 1298.

Karapandzova, M., Stefkov, G., Kulevanova, S., 2010b. Essential oils composition of Pinus peuce Griseb. (Pinaceae) growing on Pelister Mtn., Republic of Macedonia. Macedonian Pharmaceutical Bulletin 56, 13-22.

Karapandzova, M., Stefkov, G., Trajkovska-Dokik, E., Kadifkova-Panovska, T., Kaftandzieva, A., Kulevanova, S., 2011. Chemical composition of essential oils of Pinus peuce Griseb. from Macedonian flora. In: Journal of Essential Oil Research, Abstract Book of $42^{\text {th }}$ International Symposium on Essential Oils, Antalya, Turkey.

Koukos, P.K., Papadopoulou, K.I., Patiaka, D., Papagiannopoulos, 
A.D., 2000. Chemical composition of essential oils from needles and twigs of Balkan pine (Pinus peuce Grisebach) grown in Northern Greece. Journal of Agricultural and Food Chemistry 14, 1266-1268.

Kupcinskiene, E., Stikliene, A., Judzentiene, A., 2008. The essential oil qualitative and quantitative composition in the needles of Pinus sylvestris L. growing along industrial traces. Environmental Pollution 20, 1-11.

Maciag, A., Milakovic, D., Christensen, H.H., Antolovic, V., Kalemba, D., 2007. Essential oil composition and plantinsect relations in scots pine (Pinus sylvestris L.). Food Chemistry and Biotechnology 1008, 71-95.

Menkovic, N.R., Ristic, M.S., Samardzic, Z.J., Kovacevic, N.N., Tasic, S.R., 1993. Investigations of relic Pinus species . II. The essential oil of Pinus heldreichii. ISHS Acta Horticulturae 344.

Micevski, K., 1985. The flora of SR Makedonija. Macedonia Academy of Science and arts, Skopje. 1(1), 78-81.

Naydenov, K., Tremblay, F., Fenton, N., Alexandrov, A., 2006. Strucure of Pinus nigra Arn. populations in Bulgaria revealed by chloroplast microsatellites and terpenes analysis: Provanance tests. Biochemical Systematics and Ecology 34, 562-574.

Nikolic, B., Ristic, M., Bojovic, S., Marin, P.D., 2007. Variability of the needle essential oils of Pinus heldreichii from different populations in Montenegro and Serbia. Chemistry and Biodiversity 4, 905-916.

Nikolic, B., Ristic, M., Bojovic, S., Marin, P.D., 2008. Variability of the needle essential oils of Pinus peuce from different populations in Montenegro and Serbia. Chemistry and Biodiversity 5, 1377-1388.

Oluwadayo Sonibare, O., Olakunle, K., 2008. Chemical composition and antibacterial activity of the essential oil of Pinus caribaea from Nigeria. African Journal of Biotechnology 7(14), 2462-2464.

Pagula, F., Baeckstrom, P., 2006. Studies on essential oil-bearing plants from mozambique: Part II. volatile leaf oil of needles of Pinus elliotti Engelm. and Pinus taeda L.. Journal of Essential Oil Research. 18 (1), 32-34.

Papadopoulou, K., Koukos, P., 1996. Variation of the essential oils of the leaves, twigs and cones of Balkan pine (Pinus peuce Grisebach) grown in Greece. Journal of Essential Oil Research 8 (5), 499-502.

Petrakis, P.V., Tsitsimpikou, C., Tzakou, O., Couladis, M., Vagias, C., Roussis, V., 2001. Needle volatiles from five Pinus species growing in Greece. Flavour and Fragrance Journal 16 (4), 249-252.

Reichling, J., 1999a. Plant-microbe interaction and secondary metabolites with antiviral, antibacterial and antifungal properties. Functions of Plant Secondary Metabolite and their Exploitation in Biotechnology, Annual Plant Review. Sheffieled Acad. Press. 187-273.

Reichling, J., Harkenthal, M., Saller, R., 1999b. In-vitro-
Untersuchungen zur antimicrobiellen Wirkung ausgewahlter atherischer Ole. Erfahrungsheilkunde 48, 357-366.

Roussis, V., Petracis, P.V., Ortiz, A., Mazomenos, B.E., 1994. Volatile constituents of needles of five Pinus species grown in Greece. Phytochemistry 39 (2), 357-361.

Sacchetti, G., Maietti, S., Muzzoli, M., Scaglianti, M., Manfredini, S., Radice, M., Bruni, R., 2005. Comparative evaluation of 11 essential oils of different origin as functional antioxidants, antiradicals and antimicrobials in foods. Food Chemistry 91, 621-632.

Semiz, G., Heijari, J., Isik, K., Holopainen, J.K., 2007. Variation in needle terpenoids among Pinus sylvestris L. (Pinaceae) provenances in Turkey. Biochemical Systematics and Ecology 35, 652-661.

Stevanovic, T., Garneau, F.X., Jean, F.I., Gagnon, H., Vilotic, D., Petrovic, S., Ruzic, N., Pichette, A., 2005. The essential oil composition of Pinus mugo Turra from Serbia. Flavour and Fragrance Journa. 20 (1), 96-97.

Svoboda, K.P., Deans, S.G., 1995. Biological activity of essential oils from selected aromatic plants. Acta Hortic. 390, 203209.

Takarada, K., Kimizuka, R., Takahashi, N., Honma, K., Okuda, K., Kato, K., 2004. A comparation of the antibacterial efficacies of essential oils against oral pathogens. Oral Microbiol. Immunol. 19, 61-64.

Tognolini, M., Barocelli, E., Ballabeni, V., Bruni, R., Bianchi, A., Chiavarini, M., Impicciatore, M., 2006. Comparative screening ofplant essential oils: Phenylpropanoid moiety as basic core for antiplatelet activity. Life Science 78, 14191432.

Ucar, G., Balaban, M., 2004. Volatile needle extractives of Anatolian black pine varieties: $P$. nigra subsp. pallasiana var. pallasiana and var. pyramidata. Biochemical Systematics and Ecology 32, 983-992.

Ulrich, F., Schneele, J., Schmitt, S., Reichling, J., 2008. Efficacy, absorption and safety of essential oils. Dermatologic, Cosmeceutic, and Cosmetic Development (Therapeutic and Novel Approaches), Informa Heathcare 401-418.

Ustun, O., Sezik, E., Kurkcuoglu, M., Baser, K.H.C., 2006. Study of the essential oil composition of Pinus sylvestris from Turkey. Khimiya Prirodnykh Soedinenii 1, 22-25.

Weseler, A., Greiss, H.K., Saller, R., Reichling, J., 2005. A novel colorimetric broth microdilution method to determine minimum inhibitory concentration (MIC) of antibiotics and essential oils against Helicobacter pylori. Pharmazie 60, 498-502.

Youesf, R., Tawil, G., 1980. Antimicrobial activity of volatile oils. Pharmazie 35, 698-701.

Youg-Suk, K., Dong-Hwa, Sh., 2005. Volatile components and antibacterial effects of pine needle (Pinus densiflora $\mathrm{S}$. and Z.) extracts. Food Microbiology 22, 37-45. 


\title{
Антимикробна активност на етерично масло од иглички од молика (Pinus peuce Griseb., Pinaceae) од флората на Р. Македонија
}

\author{
Марија Карапанџова ${ }^{1 *}$, Гоше Стефков ${ }^{1}$, Елена Трајковска-Докиќ ${ }^{2}$ \\ Ана Кафтанџиева ${ }^{2}$, Светлана Кулеванова ${ }^{1}$ \\ ${ }^{1}$ Институт за Фармакогнозија, Фармацевтски факултет, Универзитет „, Св. Кирил и Методиј“, Скопје, \\ Македонија \\ ${ }^{2}$ Институт за Микробиологија, Медицински факултет, Универзитет „, Св. Кирил и Методиј“, Скопје, Македонија \\ Клучни зборови: Pinus реисе, Македонски бор, хемиски состав на етерично масло, GC/FID/MS, антимикробна активност. \\ Хемиски состав и антимикробна активност се испитувани кај етерично масло добиено со дестилација со водена пареа на иг- \\ лички од молика (Pinus peuce Griseb., Pinaceae) која самоникнато расте на три различни локалитети во Р. Македонија. Со GC/ \\ FID/MS анализа, идентификувани се 103 компоненти што припаѓаат на шест различни класи соединенија: монотерпенски ја- \\ глеводороди, оксидирани монотерпени, сесквитерпенски јаглеводороди, оксидирани сесквитерпени, дитерпени и други нетере- \\ пенски компоненти и истите сочинуваат $86,61 / 94,04 \%$ од севкупното масло. Најзастапени компоненти во етеричното масло се \\ $\alpha$-пинен $(12,89 / 27,34 \%), \beta$-пинен $(6,16 / 13,13 \%)$, лимонен $+\beta$-феландрен $(2,09 / 6,64 \%)$ и борнил ацетат $(2,92 / 11,67 \%)$, како и trans \\ (Е)-кариофилен $(4,63 / 7,13 \%)$ и гермакрен $\mathrm{D}(8,75 / 20,14 \%)$. \\ Антимикробната активност на етерични масла од иглички од молика е испитувана со агар дифузиона и со агар дилуциона \\ метода на 13 бактериски изолати на Грам позитивни и Грам негативни бакетии и еден изолат на габата Candida albicans. Најголе- \\ ма осетливост на дејството на маслата од молика покажа бактеријата Streptococcus pneumoniae, следена од Staphylococcus aureus, \\ Staphylococcus epidermidis, Streptococcus agalactiae, Acinetobacter spp. и Streptococcus pyogenеs. Минималните инхибиторни кон- \\ центрации на етеричните маслата се движат од 7,5 до $62,5 \mu \mathrm{l} / \mathrm{ml}$.
}

